\title{
EFFECTS OF DIFFERENT BIOCHAR-BASED FERTILIZERS ON THE BIOLOGICAL PROPERTIES AND ECONOMIC BENEFITS OF POD PEPPER (Capsicum annuum var. frutescens $\mathrm{L}$.)
}

\author{
ZHANG, M. - GOU, J. ${ }^{*}$ - WEI, Q. - LIU, Y. - QIN, S. \\ Institute of Soil and Fertilizer, Guizhou Academy of Agricultural Sciences / Guizhou Province \\ Engineering Research Center for Agricultural Resources and Environment \\ Guiyang 550006, P. R. China \\ *Corresponding author \\ e-mail: goujiulan@163.com \\ (Received 28 $8^{\text {th }}$ Jul 2020; accepted $14^{\text {th }}$ May 2021)
}

\begin{abstract}
Biochar-based fertilizer has been widely proposed as an amendment to improve soil quality and crop productivity, while few have explored the effects of biochar-based fertilizer on fruit quality and economic benefits. Two field experiments were conducted to investigate the effects of different biocharbased fertilizers on pod pepper yield, fruit quality, nutrient uptake and utilization, and economic benefits in Guizhou Province, China in 2018 and 2019. Results indicated that the supply of biochar-based fertilizer could significantly increase the yield and fruit quality compared to traditional fertilization practice (TFP). Furthermore, the accumulation of nitrogen $(\mathrm{N})$, phosphorus $(\mathrm{P})$ and potassium $(\mathrm{K})$, the fertilization agronomic efficiency (AE) and recovery efficiency (RE) all significantly increased. After the deduction of the corresponding fertilizer cost, the application of biochar-based fertilizer also significantly increased the net proceeds except for the biochar-based fertilizer 1 (B1) treatment.
\end{abstract}

Keywords: pod pepper, nitrate, Vitamin C, nutrient accumulation, fertilizer utilization

\section{Introduction}

China is one of the largest agricultural countries in the world. With an average annual increase rate of $4 \%$ for the crop straw production in China in the past decades, the country has also become one of the countries with the most abundant of straw resources in the world (Zeng et al., 2007; Hong et al., 2016). In addition to being used as a bioenergy source, livestock forage, culture medium and crop straws in China have long been removed from the field, which has led to a large sum of straw nutrient loss (Owaid et al., 2015; Yin et al., 2018). What is more, the proportion of crop straw returning to farmland in China (15\%) is unsatisfactory compared to the developed countries (70\% in United States, Europe) (Wang et al., 2016). Realizing the efficient use of crop straw has become an important task but the lack of research poses problems for the current green agricultural development of China.

Biochar is the stable solid biomass which has been pyrolyzed in a low oxygen environment (Laird et al., 2009), and has the potential ability to improve the soil physical properties, electrical conductivity, cation exchange capacity, fertility and crop productivity (Graber et al., 2010; Smith et al., 2010; Zhang et al., 2010, 2013; Liu et al., 2014; Gul et al., 2015; Shi et al., 2018). Many studies have also been conducted around the world to investigate the effects of biochar application on crop yields because of its role in sequestering carbon and enhancing nutrients efficiency in soil. Jin et al. (2019) reported that the application of biochar significantly increased the rapeseed yield and yield components. Graber et al. (2010) reported that biochar application significantly promoted the growth of pepper and tomato and increased the yield. Akhtar et al. (2014) 
found that the yield and quality of tomato was significantly enhanced for the supply of biochar. Gamareldawla et al. (2017) reported that the supply of biochar amendment promoted the growth of tomato and increased the yield. Agegnehu et al. (2016) reported that the combined use of biochar and nitrogen significantly increased the barley yield. Liu et al. (2017) reported that the application of biochar significantly increased the yield of maize/soybean and maize/peanut systems. Saxena et al. (2013) have shown that the supply of biochar not only increased the yield of French beans. The uptake of nitrogen, phosphorus and potassium was also found to be increased with the supply of biochar in Lactuca sativa (Nigussie et al., 2012).

Pod pepper (Capsicum annuum var. frutescens L.) is an important characteristic cash crop in Guizhou province, China. However, the yield and fruit quality of pod pepper was severely restricted by the long-term continuous cropping, low input of organic fertilizer, imbalance of soil $\mathrm{C} / \mathrm{N}$ and degraded soil fertility in recent years. There have been conducted a lot of studies on biochar, however, most of them were focused on the yield responses and soil physical properties while the mechanisms affected by biochar remain poorly understood. Therefore, the objectives of this study were: (1) to investigate the effects of different biochar-based fertilizers on pod pepper yield and fruit quality; (2) to calculate the effects of different biochar-based fertilizers on fertilizer efficiencies; (3) to evaluate the economic benefits of applying biochar-based fertilizers on pod pepper.

\section{Materials and methods}

\section{Experimental site}

The field trails were conducted at Shiban Town $\left(27^{\circ} 31^{\prime} 29^{\prime \prime} \mathrm{N}, 106^{\circ} 43^{\prime} 50^{\prime \prime}\right.$ E) in Guizhou Province, China in 2018 and 2019. The long-term average annual rainfall at Shiban Town is $1150 \mathrm{~mm}$. The long-term average temperature is $23.6{ }^{\circ} \mathrm{C}$. About 280 days in the year are frost-free. Figure 1 showed the field experiment in 2018. The previous crop was pod pepper. The field was fallow in winter. The soil chemical properties of the top $20 \mathrm{~cm}$ were as follows: $\mathrm{pH} 6.0$, organic matter $26.8 \mathrm{~g} \cdot \mathrm{kg}^{-1}$, total $\mathrm{N}$ $2.2 \mathrm{~g} \cdot \mathrm{kg}^{-1}$, available P $48.6 \mathrm{mg} \cdot \mathrm{kg}^{-1}$, exchangeable $\mathrm{K} 175.0 \mathrm{mg} \cdot \mathrm{kg}^{-1}$.

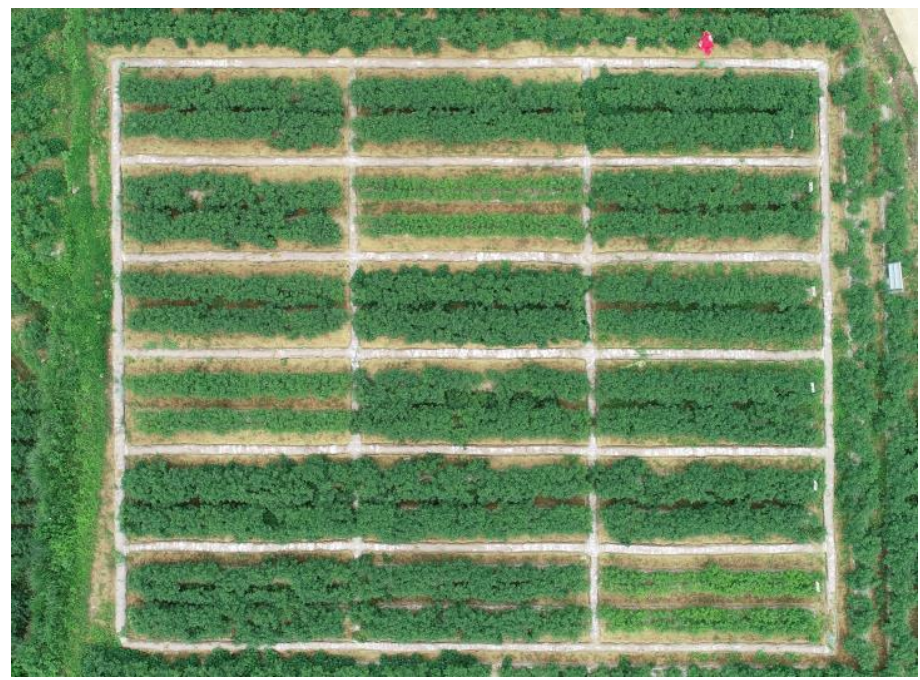

Figure 1. Photo of the field experiment 


\section{Experimental design and management}

Urea ( $\mathrm{N} 46 \%)$, compound fertilizer $\left(\mathrm{N}-\mathrm{P}_{2} \mathrm{O}_{5}-\mathrm{K}_{2} \mathrm{O}\right.$ 15-15-15), biochar-based fertilizer $1\left(\mathrm{~N}-\mathrm{P}_{2} \mathrm{O}_{5}-\mathrm{K}_{2} \mathrm{O}\right.$ 12-6-10.8, carbon $\left.10 \%\right)$, biochar-based fertilizer $2\left(\mathrm{~N}_{-} \mathrm{P}_{2} \mathrm{O}_{5}-\right.$ $\mathrm{K}_{2} \mathrm{O}$ 12-6-10.8, carbon 20\%), biochar-based fertilizer $3\left(\mathrm{~N}-\mathrm{P}_{2} \mathrm{O}_{5}-\mathrm{K}_{2} \mathrm{O}\right.$ 12-6-10.8, carbon $30 \%)$ and biochar-based fertilizer $4\left(\mathrm{~N}^{-} \mathrm{P}_{2} \mathrm{O}_{5}-\mathrm{K}_{2} \mathrm{O} 12-6-10.8\right.$, carbon $\left.40 \%\right)$ were used (Table 1). The biochar was corn straw carbon, and the carbonization temperature was

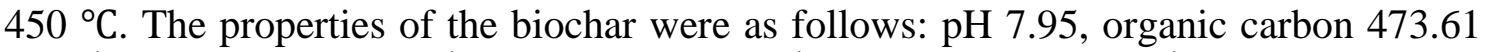
$\mathrm{g} \cdot \mathrm{kg}^{-1}$, total $\mathrm{N} 8.04 \mathrm{~g} \cdot \mathrm{kg}^{-1}$, total $\mathrm{P} 1.88 \mathrm{~g} \cdot \mathrm{kg}^{-1}$, total $\mathrm{K} 47.53 \mathrm{~g} \cdot \mathrm{kg}^{-1}$. The pod pepper variety was Yanjiao 425 (Chongqing Keguang co., LTD). Urea (N 46\%), ammonium dihydrogen phosphate $\left(\mathrm{N}-\mathrm{P}_{2} \mathrm{O}_{5} 12-60\right)$ and potassium sulfate $\left(\mathrm{K}_{2} \mathrm{O} 52 \%\right)$ were used. The biochar-based fertilizer was made with a flat grinding extrusion granulator (SKJ-120).

Table 1. The percentage composition of the applied biochar-based fertilizer

\begin{tabular}{c|c|c|c|c|c|c}
\hline $\begin{array}{c}\text { Biochar-based } \\
\text { fertilizer }\end{array}$ & Urea & $\begin{array}{c}\text { Diammonium } \\
\text { hydrogen } \\
\text { phosphate }\end{array}$ & $\begin{array}{c}\text { Potassium } \\
\text { sulphate }\end{array}$ & $\begin{array}{c}\text { Corn stalk } \\
\text { biochar }\end{array}$ & Bentonite & Binder \\
\hline B1 & 23.5 & 10 & 20.8 & 10.0 & 30.7 & 5.0 \\
B2 & 23.5 & 10 & 20.8 & 20.0 & 20.7 & 5.0 \\
B3 & 23.5 & 10 & 20.8 & 30.0 & 10.7 & 5.0 \\
B4 & 23.5 & 10 & 20.8 & 40.0 & 0.7 & 5.0 \\
\hline
\end{tabular}

Seedlings were raised in the seedbed on $20^{\text {th }}$ and $26^{\text {th }}$ Mar and transplanted on $22^{\text {nd }}$ and $29^{\text {th }}$ Apr in 2018 and 2019, respectively. The planting density was $5.2 \times 10^{4} \mathrm{ha}^{-1}$ (with a plant spacing of $30 \mathrm{~cm}$, row spacing of $60 \mathrm{~cm}$ ).

A completely randomized block design with six treatments and three replications was used. The six treatments were: no fertilizer (CK), traditional fertilization practice (TFP), biochar-based fertilizer (carbon 10\% (B1), carbon 20\% (B2), carbon 30\% (B3), carbon $40 \%$ (B4)). Compound fertilizer and biochar-based fertilizer were used as base fertilizer and turned over the soil after the fertilization. The specific fertilizer amounts were shown in Table 2. The plot area was $20 \mathrm{~m}^{2}(4.0 \mathrm{~m} \times 5.0 \mathrm{~m})$. All treatments received the same fungicide, insecticide and herbicide treatments, and no major diseases, pests or weeds were present during the growing seasons.

Table 2. Fertilizer amounts of different treatments

\begin{tabular}{c|c|c|c|c}
\hline \multirow{2}{*}{ Treatments } & \multicolumn{2}{|c|}{$\begin{array}{c}\text { Basal dressing fertilizer } \\
\left(\mathbf{k g} \cdot \mathbf{h a}^{-1}\right)\end{array}$} & $\begin{array}{c}\text { First dressing fertilizer } \\
\left(\mathbf{k g} \cdot \mathbf{h a} \mathbf{-}^{-1}\right)\end{array}$ & $\begin{array}{c}\text { Second dressing } \\
\text { fertilizer } \\
\left(\mathbf{k g} \cdot \mathbf{h a} \mathbf{-}^{-1}\right)\end{array}$ \\
\cline { 2 - 5 } & $\begin{array}{c}\text { Compound } \\
\text { fertilizer }\end{array}$ & $\begin{array}{c}\text { Biological carbon } \\
\text { fertilizer }\end{array}$ & Urea & Urea \\
\hline CK & - & - & - & - \\
TFP & 1500 & - & 300 & - \\
B1 & - & 2550 & - & - \\
B2 & - & 2550 & - & - \\
B3 & - & 2550 & - & - \\
B4 & - & 2550 & - & - \\
\hline
\end{tabular}




\section{Sampling and measurement}

Soil samples $(0-20 \mathrm{~cm})$ were collected from 10 randomly selected spots of the main experimental area one day before transplanting. The soil samples were composited and air-dried, ground and passed through $1 \mathrm{~mm}$ and $0.149 \mathrm{~mm}$ sieves for the determination of soil physicochemical characteristics. The soil chemical properties like $\mathrm{pH}$, organic matter, total $\mathrm{N}$, available $\mathrm{P}$, and exchangeable $\mathrm{K}$ were determined following the procedures of Bao (2000). Soil $\mathrm{pH}$ was measured in a 1:2.5 (soil: water ratio, w/v) extraction with a $\mathrm{pH}$ meter (FE20K, Mettler Toledo, Switzerland), organic matter was determined by wet combustion method, total $\mathrm{N}$ was determined using Kjeldahl method, available $\mathrm{P}$ was determined by sodium bicarbonate method, exchangeable $\mathrm{K}$ was extracted with ammonium acetate and boiling nitric acid, and determined with a flame photometer (FP640, Jingke, Shanghai, China).

Six plants were sampled before the final harvest, which were used to test the plant nutrition and fruit quality. The plant was divided into three parts: straw, leaf and fruit, which were heated to a constant weight at $60^{\circ} \mathrm{C}$ after heating at $105^{\circ} \mathrm{C}$ for 30 minutes. All dried samples were ground and passed through a $0.25 \mathrm{~mm}$ sieve and digested with a mixture of concentrated $\mathrm{H}_{2} \mathrm{SO}_{4}$ and $\mathrm{H}_{2} \mathrm{O}_{2}$ (Wolf, 1982) to determine $\mathrm{N}, \mathrm{P}$ and $\mathrm{K}$ concentrations. The $\mathrm{N}$ concentration was determined with a continuous flow analyzer (AA3, Seal Analytical Inc., Southampton, UK), P and K concentration was determined with an ICP-OES (optic emission spectroscopy with inductively coupled plasma, Longjumeau, HORIBA Jobin Ibon S.A.S., France). The uptake of N, P and K were calculated based on the dry mass and element concentration. At the same time, some fresh fruit samples were used to determine the quality indices. $0.1 \mathrm{~g}$ sample was mixed with nitrate-free, activated charcoal in a ratio of 1:2. The nitrate was extracted into $20 \mathrm{ml}$ of distilled water and determined using Szechrome NAS (Nambiar et al., 1988). The Vitamin $\mathrm{C}(\mathrm{Vc})$ concentration was determined by high performance liquid chromatography (HPLC) (Plaza et al., 2006). The reducing sugar concentration was according to Somogyi's method (Nii, 1997). The free amino acid concentration was determined according to Curtis et al. (2009). $0.5 \mathrm{~g}$ sample was weighed into a vial. $10 \mathrm{ml} 0.01 \mathrm{M} \mathrm{HCl}$ was added into the vial and stirred for $15 \mathrm{~min}$. After a stand of $15 \mathrm{~min}, 1.5 \mathrm{ml}$ sample was removed and centrifuged at 7200 for $15 \mathrm{~min} .100 \mu \mathrm{L}$ of the supernatant was then derivatized using the EZ-Faast amino acid derivatization technique for gas chromatography and mass spectrometry (GC-MS) (Phenomenex, Torrance, CA) The final yield was an accumulation of whole plot based on three batches of harvest.

\section{Calculations and statistical analysis}

$$
\begin{aligned}
& \text { Nutrient accumulation }\left(\mathrm{kg} \mathrm{ha}^{-1}\right)=\text { nutrient concentration }(\%) \times \text { dry } \\
& \text { mass }\left(\mathrm{kg} \mathrm{ha}^{-1}\right) / 100
\end{aligned}
$$

Agronomic efficiency $\left(\mathrm{AE}, \mathrm{kg} \mathrm{kg}^{-1}\right)=$ (yield of the fertilized plot yield of the no fertilizer plot) / applied nutrient rate

Recovery efficiency $(\mathrm{RE}, \%)=($ total nutrient uptake of fertilized plot

- total nutrient uptake of no fertilizer plot) / applied nutrient rate $\times$

$$
100 \%
$$


The yield and nutrient uptake in the upper formulas were calculated according to dry mass.

$$
\begin{gathered}
\text { Output value }\left(\mathrm{USD} \mathrm{ha}^{-1}\right)=\text { fresh weight of pod pepper }\left(\mathrm{kg} \mathrm{ha}^{-1}\right) \times \text { unit } \\
\text { price }\left(\mathrm{USD} \mathrm{kg}^{-1}\right)
\end{gathered}
$$

Increased output value $\left(\mathrm{USD} \mathrm{ha}^{-1}\right)=$ output value with fertilizer output value without fertilizer

Net proceeds $\left(\right.$ USD $\left.\mathrm{ha}^{-1}\right)=$ output value with fertilizer - fertilizer inputs

In the calculation of economic benefits, the unit price of fresh pod pepper was 0.2922 USD $\mathrm{kg}^{-1}$, the compound fertilizer, urea, ammonium dihydrogen phosphate, potassium sulphate, corn stalk biochar, bentonite and binder were 0.3287, 0.2922, $0.4091,0.5844,0.2776,0.0438$ and $0.2922 \mathrm{USD} \mathrm{kg}^{-1}$, respectively. Considering the cost of labor, water, electricity and so on, the unit price of B1, B2, B3 and B4 was 0.4821, $0.5055,0.5289,0.5522 \mathrm{USD} \mathrm{kg}^{-1}$, respectively.

A statistical analysis was performed using SPSS 18.0 (SPSS Inc., Chicago, IL, USA). The data means were compared using the LSD test at the 5\%. The figures were conducted with Origin 8.0 (Origin Lab Corporation, USA).

\section{Results}

\section{Yield}

Effects of different treatments on yield of pod pepper were shown in Fig. 2. The application of fertilizer (traditional fertilization practice (TFP), and biochar-based fertilizer) significantly increased the fresh and dry pod pepper weight than that of no fertilizer treatment (CK), which was increased by 8815 and $2129 \mathrm{~kg} \cdot \mathrm{ha}^{-1}$ in 2018 , and 8129 and $2387 \mathrm{~kg} \cdot \mathrm{ha}^{-1}$ in 2019 on average. Compared to the TFP treatment, the fresh pod pepper was increased by $1192-4142 \mathrm{~kg} \cdot \mathrm{ha}^{-1}$ and $2104-5733 \mathrm{~kg} \cdot \mathrm{ha}^{-1}$ in 2018 and 2019 for the supply of biochar-based fertilizer, the increase rate was $7.6-24.4 \%$ and 15.0-40.8\%, respectively. The treatment of biochar-based fertilizer 3 (B3) showed the highest fresh pod pepper weight in two years, which was 19930 and $19588 \mathrm{~kg} \cdot \mathrm{ha}^{-1}$. The yield of dry pod pepper was similar to that of fresh. Compared to the TFP treatment, the dry pod pepper was increased by 409-1018 kg ha-1 and 441-1482 $\mathrm{kg} \mathrm{ha}^{-1}$ in 2018 and 2019 for the supply of biochar-based fertilizer, the increase rate was $10.9-27.1 \%$ and $15.1-50.8 \%$, respectively. The treatment of B3 showed the highest dry pod pepper weight with 4776 and $4398 \mathrm{~kg} \cdot \mathrm{ha}^{-1}$ in 2018 and 2019, which was significantly higher than that of TFP.

\section{Fruit quality}

Various parameters of fruit quality are presented in Table 3. The nitrate and Vitamin $\mathrm{C}$ (Vc) concentration of fresh pod pepper were significantly increased for the application of biochar-based fertilizer, while that of reducing sugar and free amino acid concentration had no significant effects. Compared to the TFP treatment, the nitrate concentration of fresh pod pepper was decreased by $0.1-4.2 \%$ and $11.5-23.1 \%$ for the 


$$
-2834 \text { - }
$$

application of biochar-based fertilizer. The fresh pod pepper of B3 treatment showed the minimum nitrate concentration in both two years. Compared to the TFP treatment, the $\mathrm{Vc}$ concentration of fresh pod pepper was increased by $2.0-14.5 \%$ and $0.7-15.4 \%$ in 2018 and 2019 for the application of biochar-based fertilizer. The fresh pod pepper of B3 treatment showed the maximum concentration of $\mathrm{Vc}$ in both two years. The reducing sugar and free amino acid showed no significant differences between different treatments.
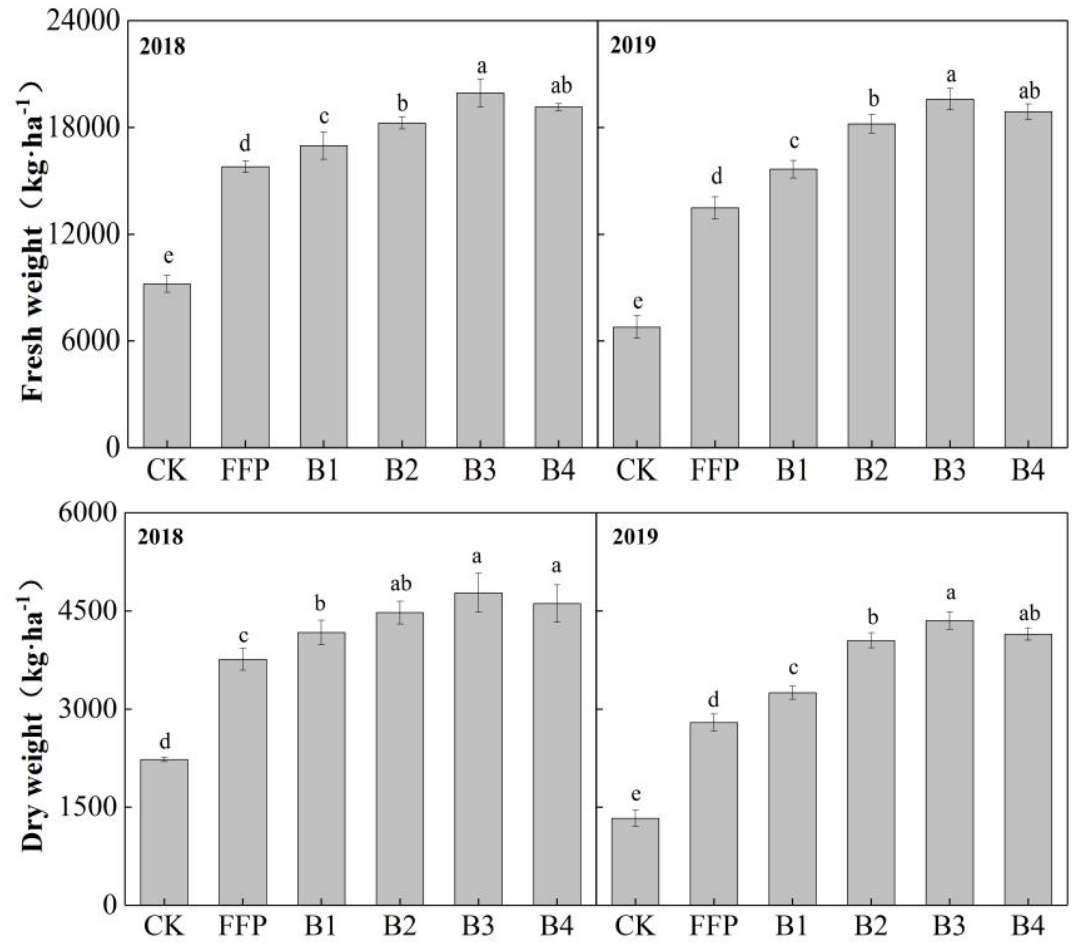

Figure 2. Effects of different treatments on fresh and dry yield of pod pepper. Different letters indicate significant indicate difference at 5\% level. The same as below. Different letters in the same column means significant difference at $5 \%$ level

Table 3. Effects of different treatments on quality of fresh pod pepper

\begin{tabular}{|c|c|c|c|c|c|}
\hline Year & Treatments & $\begin{array}{l}\text { Nitrate } \\
\left(\mathbf{m g} \cdot \mathbf{k g}^{-1}\right)\end{array}$ & $\begin{array}{c}\mathrm{Vc} \\
\left(\mathrm{mg} \cdot 100 \mathrm{~g}^{-1}\right)\end{array}$ & $\begin{array}{c}\text { Reducing sugar } \\
\left(\mathbf{g} \cdot \mathrm{kg}^{-1}\right)\end{array}$ & $\begin{array}{c}\text { Free amino acid } \\
\left(\mathrm{g} \cdot \mathrm{kg}^{-1}\right)\end{array}$ \\
\hline \multirow{6}{*}{2018} & CK & $90.4 \pm 1.4 \mathrm{bc}$ & $87.2 \pm 0.3 \mathrm{f}$ & $24.3 \pm 1.4 \mathrm{a}$ & $5.8 \pm 0.1 \mathrm{a}$ \\
\hline & TFP & $92.9 \pm 0.4 \mathrm{a}$ & $90.2 \pm 0.3 \mathrm{e}$ & $23.4 \pm 0.2 \mathrm{a}$ & $5.8 \pm 0.1 \mathrm{a}$ \\
\hline & B1 & $92.8 \pm 1.2 \mathrm{a}$ & $92.0 \pm 0.3 \mathrm{~d}$ & $23.7 \pm 0.5 \mathrm{a}$ & $5.7 \pm 0.2 \mathrm{a}$ \\
\hline & B2 & $90.7 \pm 0.7 \mathrm{~b}$ & $93.7 \pm 0.2 \mathrm{c}$ & $23.5 \pm 0.9 \mathrm{a}$ & $5.6 \pm 0.1 \mathrm{a}$ \\
\hline & B3 & $89.0 \pm 0.2 \mathrm{c}$ & $103.3 \pm 0.4 \mathrm{a}$ & $22.8 \pm 1.8 \mathrm{a}$ & $5.8 \pm 0.2 \mathrm{a}$ \\
\hline & B4 & $91.2 \pm 1.3 \mathrm{ab}$ & $94.2 \pm 0.1 \mathrm{~b}$ & $23.3 \pm 0.8 \mathrm{a}$ & $5.8 \pm 0.1 \mathrm{a}$ \\
\hline \multirow{6}{*}{2019} & CK & $76.5 \pm 0.2 \mathrm{~b}$ & $72.1 \pm 0.4 \mathrm{e}$ & $26.8 \pm 0.4 \mathrm{a}$ & $5.9 \pm 0.2 \mathrm{a}$ \\
\hline & TFP & $86.9 \pm 0.8 \mathrm{a}$ & $85.3 \pm 0.4 \mathrm{~d}$ & $26.5 \pm 0.4 \mathrm{a}$ & $5.9 \pm 0.1 \mathrm{a}$ \\
\hline & B1 & $76.9 \pm 0.9 \mathrm{~b}$ & $85.9 \pm 0.3 \mathrm{~d}$ & $27.0 \pm 0.7 \mathrm{a}$ & $5.9 \pm 0.2 \mathrm{a}$ \\
\hline & B2 & $75.0 \pm 0.4 \mathrm{c}$ & $93.0 \pm 0.7 \mathrm{c}$ & $28.1 \pm 0.6 \mathrm{a}$ & $5.8 \pm 0.1 \mathrm{a}$ \\
\hline & B3 & $72.0 \pm 0.4 \mathrm{~d}$ & $98.4 \pm 0.4 \mathrm{a}$ & $27.6 \pm 0.5 \mathrm{a}$ & $5.9 \pm 0.1 \mathrm{a}$ \\
\hline & B4 & $66.8 \pm 0.5 \mathrm{e}$ & $94.8 \pm 0.6 b$ & $27.1 \pm 0.6 \mathrm{a}$ & $5.9 \pm 0.1 \mathrm{a}$ \\
\hline
\end{tabular}

Note: Different letters in the same column means significant difference at $5 \%$ level 


\section{Accumulation of nitrogen, phosphorous and potassium}

The accumulation of $\mathrm{N}, \mathrm{P}$ and $\mathrm{K}$ was shown in Fig. 3. The application of fertilizer significantly increased the $\mathrm{N}, \mathrm{P}$ and $\mathrm{K}$ accumulation rates than that of $\mathrm{CK}$, the average increase rate was $151.5 \%, 109.7 \%$ and $134.0 \%$ in $2018,201.9 \%, 243.5 \%$ and $184.1 \%$ in 2019, respectively. Compared to the TFP treatment, the N, P and K accumulation was increased by $19.0-34.8 \%, 9.4-28.3 \%$ and $28.4-51.7 \%$ in 2018 , and $6.7-38.9 \%$, 15.0-55.0\% and 20.4-60.0\% in 2019 for the supply of biochar-based fertilizer. The treatment of B3 showed the highest $\mathrm{N}, \mathrm{P}$ and $\mathrm{K}$ accumulation rates in both two years, which was $263.3,12.9$ and $263.2 \mathrm{~kg} \cdot \mathrm{ha}^{-1}$ in 2018 and $231.7,11.0$ and $255.1 \mathrm{~kg} \cdot \mathrm{ha}^{-1}$ in 2019 , respectively.
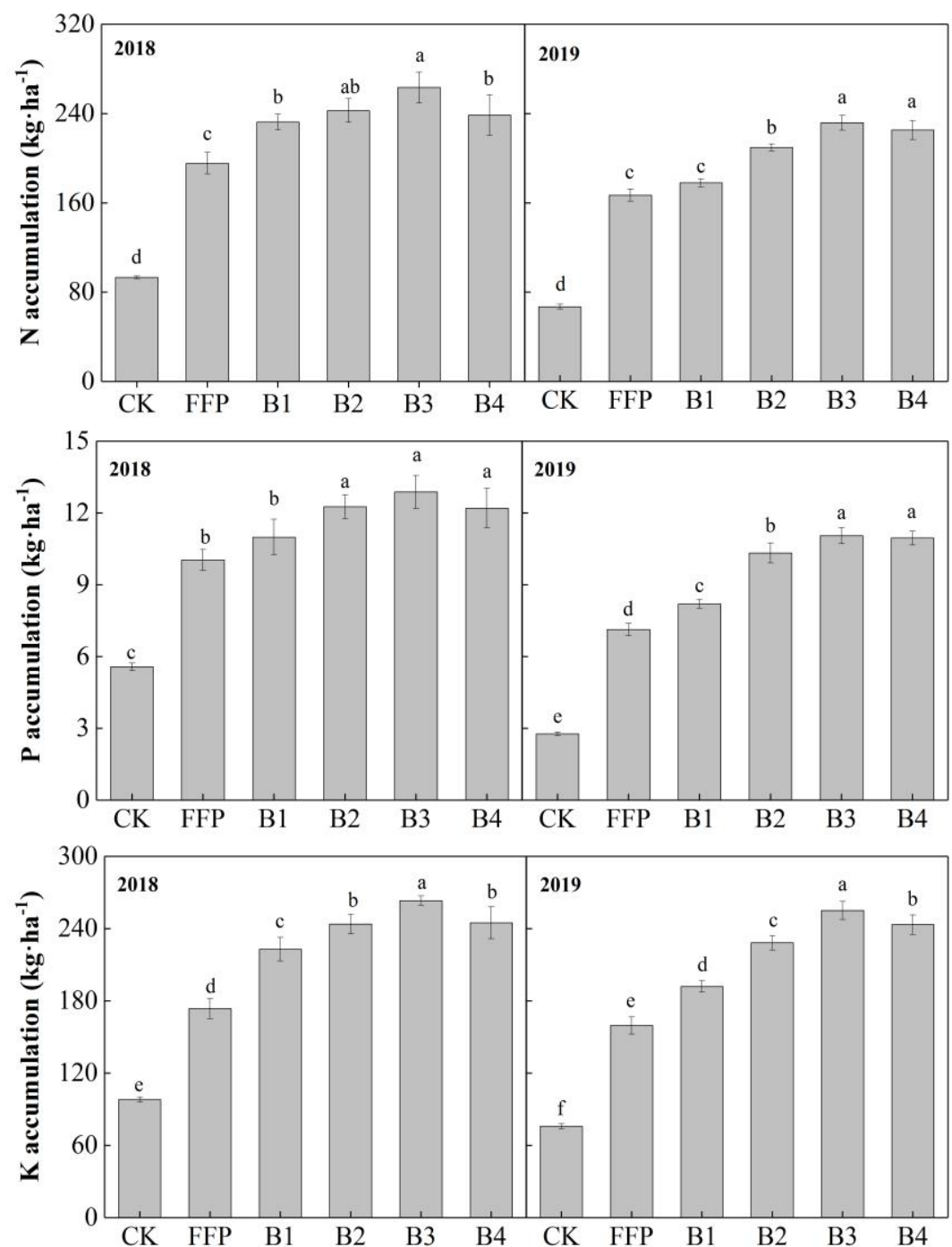

Figure 3. The N, $P$ and $K$ accumulation rates of different treatments in 2018 and 2019. Different letters in the same column means significant difference at 5\% level

\section{Efficiency of fertilizer}

The agronomic efficiency (AE) and recovery efficiency (RE, \%) was shown in Table 4. Compared to the TFP treatment, the AE of $\mathrm{N}, \mathrm{P}$ and $\mathrm{K}$ was increased by 
93.4-166.8\%, 73.7-139.5\% and 3.1-33.1\%, respectively for the supply of biochar-based fertilizer in 2018, and that was increased by $116.4-212.7 \%, 94.6-181.2 \%$ and $8.1-56.0 \%$ respectively in 2019. The treatment of $\mathrm{B} 3$ showed the highest $\mathrm{AE}$ of $\mathrm{N}, \mathrm{P}$ and $\mathrm{K}$ in both years, which was $35.1,70.1$ and $39.0 \mathrm{~kg} \cdot \mathrm{kg}^{-1}$ in 2018 , and $41.9,83.8$ and $46.5 \mathrm{~kg} \cdot \mathrm{kg}^{-1}$ in 2019, respectively. Compared to the TFP treatment, the RE of N P and K in 2018 was increased by $24.8-34.9 \%, 3.9-6.7 \%$ and $14.2-31.9 \%$, and that was increased by $82.4-$ $170.4 \%, 84.1-97.7 \%$ and $13.4-52.7 \%$ in 2019, respectively. The treatment of B3 showed the highest RE of N, P and K in both years, which was $54.8 \%, 11.9 \%$ and $75.2 \%$ in 2018 , and $53.8 \%, 12.4 \%$ and $78.4 \%$ in 2019 , respectively.

Table 4. Fertilizer utilization of different treatments

\begin{tabular}{|c|c|c|c|c|c|c|c|}
\hline \multirow{2}{*}{ Year } & \multirow{2}{*}{ Treatments } & \multicolumn{3}{|c|}{ AE $\left(\mathrm{kg} \cdot \mathrm{kg}^{-1}\right)$} & \multicolumn{3}{|c|}{ RE (\%) } \\
\hline & & $\mathbf{N}$ & $\mathbf{P}$ & $\mathbf{K}$ & $\mathbf{N}$ & $\mathbf{P}$ & $\mathbf{K}$ \\
\hline \multirow{6}{*}{2018} & CK & - & - & - & - & - & - \\
\hline & TFP & $13.1 \pm 1.4 \mathrm{~d}$ & $29.3 \pm 3.2 \mathrm{~d}$ & $29.3 \pm 3.2 \mathrm{~cd}$ & $19.9 \pm 2.1 \mathrm{c}$ & $5.2 \pm 0.5 \mathrm{c}$ & $40.4 \pm 4.4 \mathrm{~d}$ \\
\hline & B1 & $25.4 \pm 1.8 \mathrm{c}$ & $50.8 \pm 3.6 \mathrm{c}$ & $30.2 \pm 2.0 \mathrm{~d}$ & $44.7 \pm 2.5 \mathrm{~b}$ & $9.1 \pm 1.3 \mathrm{~b}$ & $54.6 \pm 5.1 \mathrm{c}$ \\
\hline & B2 & $29.6 \pm 0.7 \mathrm{~b}$ & $59.1 \pm 1.5 \mathrm{~b}$ & $32.9 \pm 0.8 \mathrm{bc}$ & $48.0 \pm 3.2 \mathrm{ab}$ & $11.0 \pm 0.7 \mathrm{ab}$ & $63.7 \pm 3.7 \mathrm{~b}$ \\
\hline & B3 & $35.1 \pm 1.3 \mathrm{a}$ & $70.1 \pm 2.6 \mathrm{a}$ & $39.0 \pm 1.5 \mathrm{a}$ & $54.8 \pm 4.4 \mathrm{a}$ & $11.9 \pm 1.0 \mathrm{a}$ & $72.2 \pm 2.0 \mathrm{a}$ \\
\hline & B4 & $32.5 \pm 1.9 \mathrm{a}$ & $65.0 \pm 3.9 \mathrm{a}$ & $36.1 \pm 2.2 \mathrm{ab}$ & $46.7 \pm 5.7 \mathrm{ab}$ & $10.9 \pm 1.3 \mathrm{ab}$ & $64.2 \pm 6.1 \mathrm{ab}$ \\
\hline \multirow{6}{*}{2019} & CK & - & - & - & - & - & - \\
\hline & TFP & $13.4 \pm 1.4 \mathrm{c}$ & $29.8 \pm 3.3 \mathrm{c}$ & $29.8 \pm 3.3 \mathrm{c}$ & $19.9 \pm 1.5 \mathrm{~d}$ & $4.4 \pm 0.2 \mathrm{~d}$ & $44.8 \pm 2.9 \mathrm{~d}$ \\
\hline & B1 & $29.0 \pm 2.8 \mathrm{~b}$ & $58.0 \pm 4.9 \mathrm{~b}$ & $32.2 \pm 2.7 \mathrm{~b}$ & $36.3 \pm 1.7 \mathrm{c}$ & $8.1 \pm 0.2 \mathrm{c}$ & $50.8 \pm 1.4 \mathrm{c}$ \\
\hline & B2 & $37.3 \pm 1.2 \mathrm{a}$ & $74.7 \pm 2.4 \mathrm{a}$ & $41.5 \pm 1.3 \mathrm{a}$ & $46.6 \pm 0.9 \mathrm{~b}$ & $11.3 \pm 0.5 \mathrm{~b}$ & $66.7 \pm 2.6 \mathrm{~b}$ \\
\hline & B3 & $41.9 \pm 4.1 \mathrm{a}$ & $83.8 \pm 8.1 \mathrm{a}$ & $46.5 \pm 4.5 \mathrm{a}$ & $53.8 \pm 2.2 \mathrm{a}$ & $12.4 \pm 0.6 \mathrm{a}$ & $78.4 \pm 4.2 \mathrm{a}$ \\
\hline & B4 & $39.6 \pm 2.9 \mathrm{a}$ & $79.2 \pm 5.7 \mathrm{a}$ & $44.0 \pm 3.2 \mathrm{a}$ & $51.7 \pm 2.5 \mathrm{a}$ & $12.2 \pm 0.5 \mathrm{a}$ & $73.3 \pm 4.3 \mathrm{a}$ \\
\hline
\end{tabular}

Different letters in the same column means significant difference at $5 \%$ level

\section{Economic benefits}

Compared to the TFP treatment, the output value was increased by 348.3-1210.2 and 635.2-1786.7 USD $\cdot \mathrm{ha}^{-1}$ in 2018 and 2019 for the supply of biochar-based fertilizer, the increase rate was $18.1-62.9 \%$ and $16.1-45.4 \%$, respectively (Table 5). The treatment of B3 showed the highest net proceeds of all treatments in both years.

Table 5. Effects of different treatments on economic benefits

\begin{tabular}{|c|c|c|c|c|c|}
\hline Year & Treatments & $\begin{array}{l}\text { Output value } \\
\left(\mathbf{U S D} \cdot \mathbf{h a}^{-1}\right)\end{array}$ & $\begin{array}{c}\text { Output value } \\
\text { with fertilizer } \\
\left(\mathrm{USD} \cdot \mathrm{ha}^{-1}\right)\end{array}$ & $\begin{array}{l}\text { Fertilizer inputs } \\
\quad\left(\mathrm{USD} \cdot \mathbf{h a}^{-1}\right)\end{array}$ & $\begin{array}{l}\text { Net proceeds } \\
\left(\text { USD } \cdot \mathbf{h a}^{-1}\right)\end{array}$ \\
\hline 2018 & $\begin{array}{c}\text { CK } \\
\text { TFP } \\
\text { B1 } \\
\text { B2 } \\
\text { B3 } \\
\text { B4 } \\
\end{array}$ & $\begin{array}{c}2688.8 \pm 115.9 \mathrm{e} \\
4613.0 \pm 98.0 \mathrm{~d} \\
4961.3 \pm 224.5 \mathrm{c} \\
5331.9 \pm 98.2 \mathrm{~b} \\
5823.2 \pm 230.8 \mathrm{a} \\
5593.3 \pm 57.7 \mathrm{ab}\end{array}$ & $\begin{array}{c}- \\
1924.2 \pm 210.8 \mathrm{~d} \\
2272.4 \pm 163.3 \mathrm{c} \\
2643.2 \pm 68.4 \mathrm{~b} \\
3134.5 \pm 119.6 \mathrm{a} \\
2904.5 \pm 173.6 \mathrm{ab}\end{array}$ & $\begin{array}{c}- \\
668.4 \\
1230.2 \\
1289.8 \\
1349.5 \\
1409.1 \\
\end{array}$ & $\begin{array}{c}- \\
1255.8 \pm 210.8 \mathrm{bc} \\
1042.2 \pm 163.3 \mathrm{c} \\
1353.3 \pm 68.4 \mathrm{~b} \\
1785.0 \pm 119.6 \mathrm{a} \\
1495.4 \pm 173.6 \mathrm{~b}\end{array}$ \\
\hline 2019 & $\begin{array}{c}\text { CK } \\
\text { TFP } \\
\text { B1 } \\
\text { B2 } \\
\text { B3 } \\
\text { B4 }\end{array}$ & $\begin{array}{c}1978.7 \pm 187.4 \mathrm{e} \\
3936.6 \pm 182.3 \mathrm{~d} \\
4572.0 \pm 144.3 \mathrm{c} \\
5316.1 \pm 151.5 \mathrm{~b} \\
5723.3 \pm 175.9 \mathrm{a} \\
5518.2 \pm 125.8 \mathrm{ab}\end{array}$ & $\begin{array}{c}- \\
1958.0 \pm 218.6 \mathrm{~d} \\
2593.2 \pm 221.6 \mathrm{c} \\
3337.6 \pm 108.4 \mathrm{~b} \\
3744.6 \pm 71.1 \mathrm{a} \\
3539.7 \pm 112.8 \mathrm{~b}\end{array}$ & $\begin{array}{c}-\overline{668.4} \\
1230.2 \\
1289.8 \\
1349.5 \\
1409.1 \\
\end{array}$ & $\begin{array}{c}- \\
1289.6 \pm 218.6 \mathrm{c} \\
1363.0 \pm 221.6 \mathrm{c} \\
2047.8 \pm 108.4 \mathrm{~b} \\
2395.1 \pm 71.1 \mathrm{a} \\
2130.6 \pm 112.8 \mathrm{~b}\end{array}$ \\
\hline
\end{tabular}

Different letters in the same column means significant difference at $5 \%$ level 


\section{Discussion}

Biochar has been used as an amendment to improve the soil fertility and increase crop yield. The results of this study are similar to those of previous studies that the supply of biochar-based fertilizer significantly increased the plant growth, carbon storage and crop yield. Compared to the TFP treatment, the fresh and dry mass of pod pepper was increased for the supply of biochar-based fertilizer. Gathorne-Hardy et al. (2009) reported that the application of biochar combined with $\mathrm{N}$ fertilizer increased the grain yield of spring barley by $30 \%$ compared to $\mathrm{N}$ fertilizer only. Zhu et al. (2015) reported that the combined use of biochar and inorganic fertilizer could increase maize biomass by 2.7-3.5 times relative to the inorganic fertilizer alone. In this research, the supply of biochar increased the dry pod pepper by $40.8 \%$ and $50.8 \%$, respectively. Several studies have been conducted to account for the mechanisms of biochar. The supply of biochar could increase the leaf photosynthetic and transpiration rates and some other physiological properties (Kammann et al., 2011; Wang et al., 2014). The application of biochar increased the total net soil surface area, soil aeration and water retention (Chan et al., 2007; Kolb et al., 2009). The supply of biochar has been shown to change the rate of $\mathrm{N}$ cycling and reduce the $\mathrm{N}$ losses from soil, which was considered closely related to its highly porous structure, large surface area and strong ion exchange capacity (Glaser et al., 2001; Clough and Condron, 2010; Huang et al., 2014). However, elevating the $\mathrm{C} / \mathrm{N}$ ratio causes the threat of $\mathrm{N}$ immobilization (Lehmann et al., 2003). The responses of root development to the supply of biochar were associated with soil conditions and plant types, as well as to interactions between the roots and surrounding soil (Prendergast-Miller et al., 2014). It was reported that the supply of biochar could provide abundant nutrients and then stimulate root development (Abiven et al., 2015). The supply of biochar also stimulated root growth, like the root biomass, root length and root tips (Makoto et al., 2010; Joseph et al., 2010; Solaiman et al., 2012). The improvement in fruit quality also could be explained by the influence of biochar-based fertilizer on promoting the development of root to deeper soil layers (Gamareldawla et al., 2017).

The supply of biochar-based fertilizer significantly improved the fruit quality and fertilizer efficiency. The nitrate concentration was decreased while the Vc concentration was increased, respectively. Compared to the TFP treatment, the AE and RE were also significantly increased for the supply of biochar-based fertilizer. The results in this study showed that the maximum increase rate of $\mathrm{AE}$ for $\mathrm{N}, \mathrm{P}$ and $\mathrm{K}$ was significantly increased by $166.8 \%, 139.5 \%$ and $33.1 \%$, respectively for the supply of biochar-based fertilizer, and the maximum increase rate of RE for $\mathrm{N}, \mathrm{P}$ and $\mathrm{K}$ was significantly increased by $54.8 \%, 11.9 \%$ and $75.2 \%$, respectively. Biochar has been reported to influence $\mathrm{N}$ dynamics by altering the rate of transformation process (Clough and Condron, 2010; Clough et al., 2013). Singh et al. (2010) reported that the application of biochar could reduce the $\mathrm{N}$ losses from soil in terms of $\mathrm{N}_{2} \mathrm{O}$ emission and $\mathrm{NH}_{3}$ volatilization. Uzoma et al. (2011) reported that the nutrient uptake was increased due to the addition of biochar. Nigussie et al. (2012) also found that the supply of biochar could increase the uptake of $\mathrm{N}, \mathrm{P}$ and $\mathrm{K}$ in Lactuca sativa.

Economic benefit is one of the most important attributes of farmland ecosystem, which is also an index for farmers to increase production and income. The results indicated that the net proceeds were significantly increased for the supply of biocharbased fertilizer in both years. It is worth noting that the net proceeds of B1 was 213.6 USD $\cdot \mathrm{ha}^{-1}$ less than that of TFP in 2018 , even though the pod pepper yield of B1 was 
significantly higher than that of TFP. The premise of large-scale application of biochar is the economic feasibility of biochar application. However, most of the current studies focused on the plant and environment effects of applying biochar-based fertilizer, and little attention had been paid to the economic benefits. Due to the large amount of biochar applied in the early stage and the high price of biochar, the input cost of biochar is too high, and the benefit is relatively slow. In this study, the combined use of biochar and inorganic fertilizer significantly increased the pod pepper yield and economic benefit. In this study, the application rate of $2550 \mathrm{~kg} \mathrm{ha}^{-1}$ biochar-based fertilizer (carbon 30\%) is recommended as the most appropriate in the cultivation of pod pepper in Guizhou province. What is more, it is necessary to reduce the cost of raw material as much as possible to down the price of biochar-based fertilizer, and then promote the use of biochar-based fertilizer in agricultural production and further increase the farmers' economic benefits.

\section{Conclusion}

Results in this study indicated that the supply of biochar-based fertilizer significantly increased the yield and fruit quality, improved the fertilization efficiency and economic benefits of pod pepper in Guizhou province, China. Hence, the application rate of $2550 \mathrm{~kg} \mathrm{ha}^{-1}$ biochar-based fertilizer containing $30 \%$ of corn stalk biochar might be considered the optimum treatment in terms of yield, fruit quality, fertilization efficiency and economic benefits. We should take full use of straw returning to improve the soil quality and use inorganic fertilizers to maintain the soil fertility and crop demands. Although there have been many studies conducted on biochar-based fertilizer to study the plant responses, and the mechanisms that are influenced by biochar-based fertilizer remain poorly understood. More studies will be continued to study the effects of application of biochar-based fertilizer on soil and expect to provide more reliable theoretical basis and data support for the application of biochar-based fertilizer.

Acknowledgements. We are grateful for the financial support provided by the National Key Research and Development Program of China (2017YFD0200808), National Natural Science Foundation of China (No. 31860594) and the Guizhou Province Science and Technology Plan Project ([2017]1181).

\section{REFERENCES}

[1] Abiven, S., Hund, A., Martinsen, V., Cornelissen, G. (2015): Biochar amendment increases maize root surface areas and branching: a shovelomics study in Zambia. - Plant and Soil 395: 45-55.

[2] Agegnehu, G., Nelson, P. N., Bird, M. I. (2016): The effects of biochar, compost and their mixture and nitrogen fertilizer on yield and nitrogen use efficiency of barley grown on a Nitisol in the highlands of Ethiopia. - Science of the Total Environment 569-570: 869-879.

[3] Akhtar, S. S., Li, G., Andersen, M. N., Liu, F. (2014): Biochar enhances yield and quality of tomato under reduced irrigation. - Agricultural Water Management 138: 37-44.

[4] Bao, S. D. (2000): Soil agricultural-chemical analysis. - China Agricultural Press, Beijing. (in Chinese). 
[5] Chan, K. Y., Van Zwieten, L., Meszaros, I., Downie, A., Joseph, S. D. (2007): Agronomic values of greenwaste biochar as a soil amendment. - Australian Journal of Soil Research 45: 629-634.

[6] Clough, T. J., Condron, L. M. (2010): Biochar and the nitrogen cycle: introduction. Journal of Environmental Quality 39: 1218-1223.

[7] Clough, T. J., Condron, L. M., Kammann, C., Müller, C. (2013): A review of biochar and soil nitrogen dynamics. - Agronomy 3: 275-293.

[8] Curtis, T. Y., Muttucumaru, N., Shewry, P. R., Parry, M. A. J., Powers, S. J., Elmore, J. S., Mottram, D. S., Hook, S. H., Nigel, G. (2009): Effects of genotype and environment on free amino acid levels in wheat grain: implications for acrylamide formation during processing. - Journal of Agriculture and Food Chemistry 57: 1013-1021.

[9] Gamareldawla, A., She, D., Liu, Z., Nazar, E., Shao, G., Timm, L. C. (2017): Effects of deficit irrigation and biochar addition on the growth, yield, and quality of tomato. Scientia Horticulturae 222: 90-101.

[10] Gathorne-Hardy, A., Knight, J., Woods, J. (2009): Biochar as a soil amendment positively interacts with nitrogen fertiliser to improve barley yields in the UK. - IOP Conference Series Earth and Environmental Science 6: 372052.

[11] Glaser, B., Haumaier, L., Guggenberger, G., Zech, W. (2001): The 'Terra Preta' phenomenon: a model for sustainable agriculture in the humid tropics. - Die Naturwissenschaften 88: 37-41.

[12] Graber, E., Meller, H. Y., Kolton, M., Cytryn, E., Silber, A., Rav, D. D., Tsechansky, L., Borenshtein, M., Elad, Y. (2010): Biochar impact on development and productivity of pepper and tomato grown in fertigated soilless media. - Plant \& Soil 337: 481-496.

[13] Gul, S., Whalen, J. K., Thomas, B. W., Sachdeva, V., Deng, H. (2015): Physico-chemical properties and microbial responses in biochar-amended soils: mechanisms and future directions. - Agriculture Ecosystems \& Environment 206: 46-59.

[14] Hong, J., Ren, L., Hong, J., Xu, C. (2016): Environmental impact assessment of corn straw utilization in China. - Journal of Cleaner Production 112: 1700-1708.

[15] Huang, M., Yang, L., Qin, H., Jiang, L., Zou, Y. (2014): Fertilizer nitrogen uptake by rice increased by biochar application. - Biology and Fertility of Soils 50: 997-1000.

[16] Jin, Z., Chen, C., Chen, X., Hopkins, I., Zhang, X., Han, Z., Jiang, F., Billy, G. (2019): The crucial factors of soil fertility and rapeseed yield - A five-year field trial with biochar addition in upland red soil, China. - Science of the Total Environment 649: 1467-1480.

[17] Joseph, S. D., Camps-Arbestain, M., Lin, Y., Munroe, P., Chia, C. H., Hook, J. M., Van Zwieten, L., Kimber, S., Cowie, A. L., Singh, B. P., Lehmann, J., Foidl, N., Smernik, R. J., Amonette, J. E. J. (2010): An investigation into the reactions of biochar in soil. Australian Journal of Soil Research 48: 501-515.

[18] Kammann, C. I., Linsel, S., Gößling, J. W., Koyro, H. (2011): Influence of biochar on drought tolerance of Chenopodium quinoa Willd and on soil-plant relations. - Plant \& Soil 345: 195-210.

[19] Kolb, S. E., Fermanich, K. J., Dornbush, M. E. (2009): Effect of charcoal quantity on microbial biomass and activity in temperate soils. - Soil Science Society of America Journal 73: 1173-1181.

[20] Laird, D. A., Brown, R. C., Amonette, J. E., Lehmann, J. (2009): Review of the pyrolysis platform for coproducing bio-oil and biochar. - Biofuels Bioproducts \& Biorefining 3: 547-562.

[21] Lehmann, J., Pereira da Silva, J., Steiner, C., Nehls, T., Zech, W., Glaser, B. (2003): Nutrient availability and leaching in an archaeological Anthrosol and a Ferralsol of the Central Amazon basin: fertilizer, manure and charcoal amendments. - Plant and Soil 249: 343-357.

[22] Liu, Z., Chen, X., Jing, Y., Li, Q., Zhang, J., Huang, Q. (2014): Effects of biochar amendment on rapeseed and sweet potato yields and water stable aggregate in upland red soil. - Catena 123: 45-51. 
[23] Liu, L., Wang, Y., Yan, X., Li, J., Jiao, N., Hu, S. (2017): Biochar amendments increase the yield advantage of legume-based intercropping systems over monoculture. Agriculture Ecosystems \& Environment 237: 16-23.

[24] Makoto, K., Tamai, Y., Kim, Y. S., Koike, T. (2010): Buried charcoal layer and ectomycorrhizae cooperatively promote the growth of Larix gmelinii seedlings. - Plant \& Soil 327: 143-152.

[25] Nambiar, P. T. C., Rego, T. J., Srinivasa Rao, B. (1988): Nitrate concentration and nitrate reductase activity in the leaves of three legumes and three cereals. - Annals of Applied Biology 112: 547-553.

[26] Nigussie, A., Kissi, E., Misganaw, M., Ambaw, G. (2012): Effect of biochar application on soil Properties and nutrient uptake of Lettuces (Lactuca sativa) grown in chromium polluted soils. - American-Eurasian Journal of Agriculture \& Environmental Science 12: 369-376.

[27] Nii, N. (1997): Changes of starch and sorbitol in leaves before and after removal of fruits from peach trees. - Annals Botany 79: 139-144.

[28] Owaid, M. N., Abed, A. M., Nasssar, B. M. (2015): Recycling cardboard wastes to produce blue oyster mushroom Pleurotus ostreatus in Iraq. - Emirates Journal of Food Agriculture 27: 537-541.

[29] Plaza, L., Sánchez-Moreno, C., Elez-Martínez, P., De Ancos, B., Martín-Belloso, O., Cano, M. (2006): Effect of refrigerated storage on vitamin $C$ and antioxidant activity of orange juice processed by high-pressure or pulsed electric fields with regard to low pasteurization. - European Food Research and Technology 223: 487-493.

[30] Prendergast-Miller, M. T., Duvall, M., Sohi, S. P. (2014): Biochar-root interactions are mediated by biochar nutrient content and impacts on soil nutrient availability. - European Journal of Soil Science 65: 173-185.

[31] Saxena, J., Rana, G., Pandey, M. (2013): Impact of addition of biochar along with Bacillus sp. on growth and yield of French beans. - Scientia Horticulturae 162: 351-356.

[32] Shi, R., Li, J., Jiang, J., Kamran, M. A., Xu, R., Qian, W. (2018): Incorporation of corn straw biochar inhibited the re-acidification of four acidic soils derived from different parent materials. - Environmental Science and Pollution Research 25: 9662-9672.

[33] Singh, B. P., Hatton, B. J., Singh, B., Cowie, A. L., Kathuria, A. (2010): Influence of biochars on nitrous oxide emission and nitrogen leaching from two contrasting soils. Journal of Environmental Quality 39(4): 1224-1235.

[34] Smith, J. L., Collins, H. P., Bailey, V. L. (2010): The effect of young biochar on soil respiration. - Soil Biology and Biochemistry 42: 2345-2347.

[35] Solaiman, Z. M., Murphy, D. V., Abbott, L. K. (2012): Biochars influence seed germination and early growth of seedlings. - Plant \& Soil 353: 273-287.

[36] Uzoma, K. C., Inoue, M., Andry, H., Fujimaki, H., Zahoor, A., Niizar, E. (2011): Effect of cow manure biochar on maize productivity under sandy soil condition. - Soil Use and Management 27: 205-212.

[37] Wang, Y., Pan, F., Wang, G., Zhang, G., Wang, Y., Chen, X., Mao, Z. (2014): Effects of biochar on photosynthesis and antioxidative system of Malus hupehensis Rehd. seedlings under replant conditions. - Scientia Horticulturae 175: 9-15.

[38] Wang, H., Wang, F., Sun, R., Gao, C., Wang, Y., Sun, N., Wang, L. (2016): Policies and regulations of crop straw utilization of foreign countries and its experience and inspiration for China. - Transactions of the CSAE 32: 216-222. (in Chinese).

[39] Wolf, B. (1982): A comprehensive systems of leaf analysis and its use for diagnosing crop nutrients status. - Communications in Soil Science and Plant Analysis 13: 10351059.

[40] Yin, H., Zhao, W., Li, T., Cheng, X., Liu, Q. (2018): Balancing straw returning and chemical fertilizers in China: Role of straw nutrient resources. - Renewable and Sustainable Energy Reviews 81: 2695-2702. 
[41] Zeng, X., Ma, Y., Ma, L. (2007): Utilization of straw in biomass energy in China. Renewable and Sustainable Energy Reviews 11: 976-987.

[42] Zhang, A., Cui, L., Pan, G., Li, L., Hussain, Q., Zhang, X., Zheng, J., Crowley, D. (2010): Effect of biochar amendment on yield and methane and nitrous oxide emissions from a rice paddy from Tai Lake plain, China. - Agriculture Ecosystems \& Environment 139: 469-475.

[43] Zheng, H., Wang, Z., Deng, X., Herbert, S., Xing, B. (2013): Impacts of adding biochar on nitrogen retention and bioavailability in agricultural soil. - Geoderma 206: 32-39.

[44] Zhu, Q., Peng, X., Huang, T. (2015): Contrasted effects of biochar on maize growth and $\mathrm{N}$ use efficiency depending on soil conditions. - International Agrophysics 29: 257-266. 